\title{
Pelosinus defluvii sp. nov., isolated from chlorinated solvent-contaminated groundwater, emended description of the genus Pelosinus and transfer of Sporotalea propionica to Pelosinus propionicus comb. nov.
}

\author{
William M. Moe, ${ }^{1}$ Rachael E. Stebbing, ${ }^{2}$ Jyoti U. Rao, ${ }^{1}$ Kimberly S. Bowman, ${ }^{1,2}$ \\ M. Fernanda Nobre, ${ }^{3}$ Milton S. da Costa ${ }^{3}$ and Fred A. Rainey ${ }^{2}$ \\ ${ }^{1}$ Department of Civil and Environmental Engineering, Louisiana State University, Baton Rouge, \\ LA 70803, USA \\ ${ }^{2}$ Department of Biological Sciences, Louisiana State University, Baton Rouge, LA 70803, USA \\ ${ }^{3}$ Department of Life Sciences, University of Coimbra, 3001-401 Coimbra, Portugal
}

Two anaerobic bacterial strains, designated $\mathrm{SHI}-1^{\top}$ and $\mathrm{SHI}-2$, were isolated from chlorinated solvent-contaminated groundwater. They were found to be identical in phenotypic properties and shared high (98.5-99.8\%) pairwise 16S rRNA gene sequence similarity. Multiple 16S rRNA genes were found to be present in the isolates as well as Pelosinus fermentans DSM $17108^{\top}$ and Sporotalea propionica DSM $13327^{\top}$. Strains SHI- ${ }^{\top}$ and SHI-2 could be differentiated from their closest phylogenetic relatives, $P$. fermentans DSM $17108^{\top}$ and S. propionica DSM $13327^{\top}$, on the basis of their phenotypic and phylogenetic properties. The isolates were Gram-negative, spore-forming, motile rods with peritrichous flagella. Growth occurred at $10-42{ }^{\circ} \mathrm{C}$ and pH $5.5-$ 8.5. Fermentative growth was observed on Casamino acids, fructose, fumarate, glucose, glycerol, pyruvate and yeast extract. The major organic acids produced from glucose and glycerol fermentation were propionate and acetate. The major organic acids produced from fermentation of fumarate were propionate, acetate and succinate. The major cellular fatty acids were summed feature 4 (consisting of $C_{15: 1} \omega 8 \mathrm{c}$ and/or $C_{15: 2}$ ), summed feature 8 (consisting of $C_{17: 1} \omega 8 \mathrm{c}$ and/ or $\mathrm{C}_{17: 2}$ ) and $\mathrm{C}_{14: 0}$ dimethyl aldehyde. The polar lipids comprised aminophospholipids, including phosphatidylethanolamine and phosphatidylserine, and an unknown phospholipid. The genomic DNA G $+\mathrm{C}$ content was 39.2 mol\%. We propose that strains $\mathrm{SHI}^{\top}{ }^{\top}$ and $\mathrm{SHI}-2$ are assigned to a novel species of the genus Pelosinus, with the name Pelosinus defluvii sp. nov. (type strain $\mathrm{SHI}-1^{\top}$ $=$ NRRL Y $-59407^{\top}=$ LMG $\left.25549^{\top}\right)$. The description of the genus Pelosinus is emended. We also propose the transfer of $S$. propionica to the genus Pelosinus as Pelosinus propionicus comb. nov. (type strain $\operatorname{TmPN}^{\top}=\mathrm{DSM} 13327^{\top}=$ ATCC BAA-626 ${ }^{\top}$ ), on the basis of phylogenetic, chemotaxonomic and phenotypic properties.

The genus Pelosinus was described by Shelobolina et al. (2007) to accommodate a bacterium belonging to the Sporomusa-Pectinatus-Selenomonas group of the phylum Firmicutes (Strömpl et al., 1999). This group is a heterogeneous assemblage of organisms with Gram-negative cell

Abbreviation: DMA, Dimethyl aldehyde.

The GenBank/EMBL/DDBJ accession numbers for the 16S rRNA gene sequences of strains $\mathrm{SHI}-1^{\top}, \mathrm{SHI}-2, \mathrm{DSM} 17108^{\top}$ and DSM $13327^{\top}$ are JF750003-JF750008, JF750009-JF750014, JF749997-JF750002 and JF749991-JF749996, respectively.

A supplementary figure is available with the online version of this paper. walls and is also referred to as clostridial cluster IX (Collins et al., 1994) and the family Veillonellaceae (Rogosa, 1971). At present, the genus Pelosinus is represented by a single species, Pelosinus fermentans, the type strain of which was first isolated from a subsurface kaolin deposit in Russia (Shelobolina et al., 2007). The genus Sporotalea contains the single species Sporotalea propionica and was described by Boga et al. (2007) to accommodate a propionigenic bacterium isolated from the intestinal tract of the soilfeeding termite Thoracotermes macrothorax. At the time of initial publication, the closest phylogenetic relative reported for both $P$. fermentans $\mathrm{R}^{\mathrm{T}}$ (Shelobolina et al., 
2007) and S. propionica $\mathrm{TmPN}^{\mathrm{T}}{ }^{\text {(Boga et al., 2007) was }}$ Acetonema longum DSM $6540^{\mathrm{T}}$, which was first isolated from the hindgut of the wood-feeding termite Pterotermes occidentis (Kane \& Breznak, 1991).

Because the descriptions of $P$. fermentans and S. propionica as novel taxa occurred in close succession (Shelobolina et al., 2007; Boga et al., 2007), the two closely related species were assigned to separate genera. Here, we present results from a study to clarify the taxonomic relationships between P. fermentans (Shelobolina et al., 2007) and S. propionica (Boga et al., 2007) as well as two strains isolated from contaminated groundwater at the Scenic Highway portion of the PetroProcessors of Louisiana Superfund Site located near Baton Rouge, Louisiana, USA.

The groundwater from which the isolates were obtained was moderately acidic ( $\mathrm{pH}$ 5.8) and was contaminated with several halogenated solvents, including chlorinated alkanes $\left(\mathrm{l}^{-1}\right.$ : $285 \mu \mathrm{g}$ 1,1,2,2-tetrachloroethane, $5540 \mu \mathrm{g}$ 1,1,2-trichloroethane, $8890 \mu \mathrm{g}$ 1,2-dichloroethane, $4170 \mu \mathrm{g}$ 1,2-dichloropropane) and chlorinated alkenes (4640 $\mu \mathrm{g}$ tetrachloroethene, $4440 \mu \mathrm{g}$ trichloroethene, $983 \mu \mathrm{g}$ vinyl chloride). The groundwater also contained $\left(1^{-1}\right) 3.32 \mathrm{mg}$ ferrous iron and $59.3 \mathrm{mg}$ sulfate, but not nitrite or nitrate $(<0.01 \mathrm{mg} \mathrm{N})$. One isolate, designated SHI-1 ${ }^{\mathrm{T}}$, was isolated on anaerobic medium described by Sekiguchi et al. (2000) supplemented with $5 \mathrm{mM}$ ribose but with $\mathrm{Na}_{2} \mathrm{~S}$ replaced with $0.5 \mathrm{~g}$ L-cysteine hydrochloride $\mathrm{l}^{-1}$ as the reducing agent and the $\mathrm{pH}$ adjusted to $\mathrm{pH}$ 7. A second isolate, designated SHI-2, was isolated on 1/10 R2A agar (Difco) supplemented with $\left(1^{-1}\right) 0.5 \mathrm{~g} \mathrm{~L}-$ cysteine hydrochloride as the reducing agent and $1.0 \mathrm{mg}$ resazurin as the redox indicator, with incubation at $30{ }^{\circ} \mathrm{C}$ in an anaerobic chamber. The purity of the strains was verified by microscopy. Strains were preserved at $-80{ }^{\circ} \mathrm{C}$ in peptoneyeast extract-glucose (PYG) broth (Holdeman et al., 1977) supplemented with $15 \%(\mathrm{v} / \mathrm{v})$ glycerol and $5 \%(\mathrm{v} / \mathrm{v})$ DMSO. In addition to the media used for initial isolation, strains SHI- ${ }^{\mathrm{T}}$ and SHI-2 also grew well on anaerobic PYG agar $\left(15 \mathrm{~g}\right.$ agar $\left.\mathrm{l}^{-1}\right)$. For comparative purposes, $P$. fermentans DSM $17108^{\mathrm{T}}$ and S. propionica DSM $13327^{\mathrm{T}}$ were obtained from the DSMZ, Braunschweig, Germany. Unless stated otherwise, all tests were carried out in duplicate and the procedures followed strict anaerobic protocols as described by Holdeman et al. (1977).

16S rRNA gene sequences were determined as described previously (Rainey et al., 1996a). Initial attempts to sequence the 16S rRNA gene of strains SHI- $1^{\mathrm{T}}$ and SHI-2 resulted in a mixed sequence for the $5^{\prime}$ end. Inspection of the sequence of $P$. fermentans $\mathrm{R}^{\mathrm{T}}$ (accession number DQ145536) indicated that the 16S rRNA gene sequence started at Escherichia coli position 130 and not at the 5' end. To obtain complete and clean sequences of strains SHI- $1^{\mathrm{T}}$ and SHI-2, P. fermentans DSM $17108^{\mathrm{T}}$ and S. propionica DSM $13327^{\mathrm{T}}$, PCR products were cloned and sequenced as described previously (Rainey et al., 1996b). Sequencing of the clones revealed that all four strains had multiple 16S rRNA genes, which varied in size because of gene copies containing intervening sequences in variable region I. Two lengths of intervening sequences were observed, one comprising $17 \mathrm{nt}$ and the other $115 \mathrm{nt}$. The short intervening sequences for strains SHI- $1^{\mathrm{T}}$, SHI-2 and P. fermentans DSM $17108^{\mathrm{T}}$ were identical but those for S. propionica DSM $13327^{\mathrm{T}}$ differed in three positions. The long intervening sequences showed variability both within and between strains. The intervening sequences were excluded in sequence comparisons for the calculation of pairwise similarity values between strains and between cloned sequences of each strain. Complete 16S rRNA gene sequences were determined for six clones of each strain, three with the short and three with the long intervening sequences. A phylogenetic dendrogram was reconstructed by the neighbour-joining method using MEGA version 4.0.

Strains SHI- $1^{\mathrm{T}}$ and SHI-2, P. fermentans DSM $17108^{\mathrm{T}}$ and S. propionica DSM $13327^{\mathrm{T}}$ clustered within the family Veillonellaceae of the order Clostridiales and were most closely related to 'Psychrosinus fermentans' FCF9 (Sattley et al., 2008) and A. longum DSM $6540^{\mathrm{T}}$ (Kane \& Breznak, 1991). For $P$. fermentans DSM $17108^{\mathrm{T}}$, the pairwise sequence similarities between the different copies of the 16S rRNA gene ranged from 98.7 to $99.6 \%$ and similarities with the original sequence of $P$. fermentans $\mathrm{R}^{\mathrm{T}}$ (GenBank accession no. DQ145536) ranged from 98.9 to $99.4 \%$. For S. propionica DSM $13327^{\mathrm{T}}$, the pairwise sequence similarities between the different copies of the 16S rRNA gene ranged from 99.3 to $99.9 \%$ and similarities with the original sequence of S. propionica $\mathrm{TmPN}^{\mathrm{T}}$ (AM258975) ranged from 98.2 to $98.5 \%$. The relatively low pairwise similarity between the cloned sequences and those determined in the original descriptions of $P$. fermentans and S. propionica by direct sequencing of PCR products (Shelobolina et al., 2007; Boga et al., 2007) is a result of the heterogeneity in the original sequences due to the multiple gene copies. The multiple 16S rRNA gene sequences of strains $\mathrm{SHI}-1^{\mathrm{T}}$ and SHI-2 shared $98.5-99.8 \%$ pairwise similarity and were shown to be interrelated in the phylogenetic analysis (Fig. 1). This was in contrast to the cloned sequences of $P$. fermentans DSM $17108^{\mathrm{T}}$ and $S$. propionica DSM $13327^{\mathrm{T}}$, which clustered separately. Strains SHI- $1^{\mathrm{T}}$ and SHI-2 shared $97.3-97.9 \%$ sequence similarity with S. propionica DSM $13327^{\mathrm{T}}$ and $97.0-98.3 \%$ sequence similarity with $P$. fermentans DSM $17108^{\mathrm{T}}$. The low $16 \mathrm{~S}$ rRNA gene sequence similarities as well as the phylogenetic positions (Fig. 1) supported the distinct single-species status of strains SHI- $1^{\mathrm{T}}$ and SHI-2.

The finding that 16S rRNA genes with intervening sequences of varying lengths were present in strains $\mathrm{SHI}-1^{\mathrm{T}}$ and SHI-2 as well as P. fermentans DSM $17108^{\mathrm{T}}$ and $S$. propionica DSM $13327^{\mathrm{T}}$, which were isolated from very different environments and geographically distinct regions, is interesting. Such intervening sequences were also detected in the phylogenetically related strain UFO1 (Fig. 1), which was isolated from sediments at the Oak Ridge Integrated Field Research Challenge site in Tennessee, USA (Ray et al., 2010). Intervening sequences at variable 


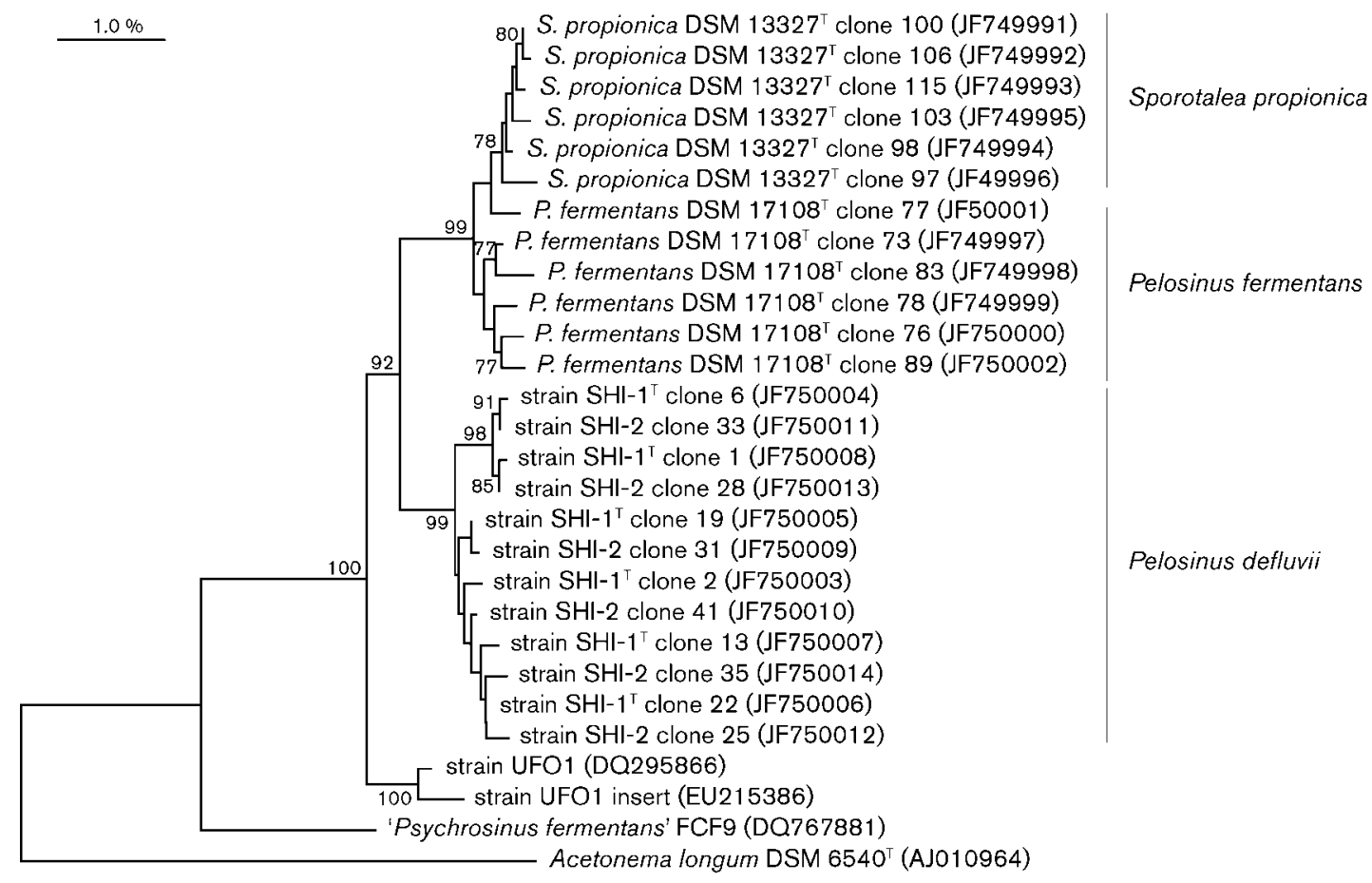

Fig. 1. Phylogenetic tree based on $16 \mathrm{~S}$ rRNA gene sequences showing the relationships of strains $\mathrm{SHI}-1^{\top}$ and $\mathrm{SHI}-2$ with $S$. propionica DSM $13327^{\top}$, P. fermentans DSM $17108^{\top}$ and related strains. Bootstrap values $(>70 \%)$ for 1000 replicates are shown at branching nodes. Bar, 1 substitution per 100 nucleotide positions.

region I are not uncommon in the class Clostridia and have been observed in Clostridium paradoxum (Rainey et al., 1996b) and the distantly related taxa Desulfotomaculum (Stackebrandt et al., 1997), Desulfitobacterium (Villemur et al., 2007) and Carboxydothermus hydrogenoformans (Wu et al., 2005).

Colony morphology was observed after growth on anaerobic PYG agar in an anaerobic chamber (headspace gas $\mathrm{N}_{2} / \mathrm{CO}_{2} / \mathrm{H}_{2}, 90: 5: 5, \mathrm{v} / \mathrm{v}$ ) at $33{ }^{\circ} \mathrm{C}$ for 5 days. Colonies of strains SHI- $1^{\mathrm{T}}$ and SHI-2 were circular, $1-3 \mathrm{~mm}$ in diameter, buff to off-white, translucent, convex and smooth with entire margins and a butyrous texture. Cell size, shape and morphology were observed by differential interference contrast microscopy (Microphot-FXA; Nikon) after $24 \mathrm{~h}$ in anaerobic PYG broth at $30{ }^{\circ} \mathrm{C}$. Cells of strains SHI- ${ }^{\mathrm{T}}$ and SHI-2 were observed to be motile, straight to slightly curved rods $(0.6-1 \times 2-7 \mu \mathrm{m})$. Peritrichous flagella were observed in cell preparations negatively stained with uranyl acetate and imaged by transmission electron microscopy (100CX; JEOL) as described by Bae et al. (2007). Cells of SHI- $1^{\mathrm{T}}$ and SHI-2 were Gram-negative with both the BD kit and the $\mathrm{KOH}$ test (Powers, 1995). After 8 days under the same conditions, both strains exhibited terminal, spherical, bulging spores.

The temperature range for growth of the isolates and the reference strains was assessed in PYG broth with a headspace gas comprised of $\mathrm{N}_{2} / \mathrm{CO}_{2}(80: 20, \mathrm{v} / \mathrm{v})$ at $4,7,10,15$,
$22,26,30,33,37,40,42$ and $50{ }^{\circ} \mathrm{C}$. The $\mathrm{pH}$ range for growth at $33{ }^{\circ} \mathrm{C}$ was evaluated at $\mathrm{pH} 5.0-10.5$ (at intervals of $0.5 \mathrm{pH}$ ) in anaerobic PYG broth, prepared without $\mathrm{NaHCO}_{3}$ and supplemented with $10 \mathrm{mM}$ phosphatecitrate buffer ( $\mathrm{pH}$ 5.0), MES buffer ( $\mathrm{pH}$ 5.5-6.5), HEPES buffer ( $\mathrm{pH} 7.0-8.0$ ), TAPS buffer ( $\mathrm{pH} 8.5$ ) or CAPSO buffer ( $\mathrm{pH} 9.0-10.5)$. The headspace gas was $\mathrm{N}_{2}$. Growth was scored as positive if $\mathrm{OD}_{600}$ increased by $>0.05$ absorbance units within 7 days in comparison to uninoculated controls. Strains SHI- $1^{\mathrm{T}}$ and SHI-2 and P. fermentans DSM $17108^{\mathrm{T}}$ grew at $10-42{ }^{\circ} \mathrm{C}$ (optimum $30-37^{\circ} \mathrm{C}$ ), but not at 7 or $50{ }^{\circ} \mathrm{C}$. In comparison, S. propionica DSM $13327^{\mathrm{T}}$ grew at $15-37{ }^{\circ} \mathrm{C}$ (optimum $30-37{ }^{\circ} \mathrm{C}$ ), but not at 10 or $40{ }^{\circ} \mathrm{C}$. All four test strains grew at pH 5.5-8.5. The optimum $\mathrm{pH}$ for strains SHI- ${ }^{\mathrm{T}}$, SHI-2 and P. fermentans DSM $17108^{\mathrm{T}}$ was $\mathrm{pH} 7.0-7.5$, while that for S. propionica DSM $13327^{\mathrm{T}}$ was $\mathrm{pH} 6.5-7.0$.

The ability to utilize various substrates for growth was assessed in $25 \mathrm{ml}$ glass serum bottles containing $15 \mathrm{ml}$ anaerobic medium [RJ medium, $1^{-1}: 0.348 \mathrm{~g} \mathrm{~K}_{2} \mathrm{HPO}_{4}$, $0.227 \mathrm{~g} \mathrm{KH}_{2} \mathrm{PO}_{4}, 0.50 \mathrm{~g} \mathrm{NH} 4 \mathrm{Cl}, 0.415 \mathrm{~g} \mathrm{MgCl}_{2} .6 \mathrm{H}_{2} \mathrm{O}$, $0.25 \mathrm{~g} \mathrm{CaCl}_{2} .2 \mathrm{H}_{2} \mathrm{O}, 2.25 \mathrm{~g} \mathrm{NaCl}, 1.0 \mathrm{~g}$ yeast extract, $1.0 \mathrm{mg}$ resazurin, $1.0 \mathrm{ml}$ trace element solution SL10 (Widdel et al., 1983), $10 \mathrm{ml}$ vitamin solution (Wolin et al., 1963 ) and $0.5 \mathrm{~g}$ L-cysteine hydrochloride], prepared with a headspace gas comprised of $\mathrm{N}_{2} / \mathrm{CO}_{2}(80: 20, \mathrm{v} / \mathrm{v})$ and adjusted to pH 7.2 prior to autoclaving. Each bottle was supplemented with $\left(5 \mathrm{gl}^{-1}\right)$ adonitol, amygdalin, arabinose, 
2,3-butanediol, butyrate, Casamino acids, cellobiose, dulcitol, erythritol, ethanol, formate, fructose, fucose, fumarate, glucose, glutamic acid, glycerol, glycogen, inulin, lactate, lactose, malonate, maltose, mannitol, melezitose, methanol, myo-inositol, propionate, pyrogallol, pyruvate, raffinose, rhamnose, salicin, salicylic acid, sorbitol, starch, succinate, sucrose, trehalose, xylan or yeast extract. Tests to assess the ability of the strains to utilize $\mathrm{H}_{2}+\mathrm{CO}_{2}$ were performed in anaerobic broth with the composition described above but with $15 \mathrm{ml}$ liquid volume in $60 \mathrm{ml}$ serum bottles with a headspace gas comprised of $\mathrm{H}_{2} / \mathrm{CO}_{2}(80: 20, \mathrm{v} / \mathrm{v})$. Serum bottles were inoculated with $2 \%(\mathrm{v} / \mathrm{v})$ exponential growthphase cultures grown in 1/10 peptone-yeast extract (PY) broth (Holdeman et al., 1977) and incubated at $30{ }^{\circ} \mathrm{C}$ for 3 days. Cultures exhibiting an increase in $\mathrm{OD}_{600}>0.05$ in comparison with controls not supplemented with respective substrates were scored as positive. The results for strains SHI- $1^{\mathrm{T}}$ and SHI-2 were identical and are shown in Table 1 and the species description. It should be noted that Shelobolina et al. (2007) reported that P. fermentans $\mathrm{R} 7^{\mathrm{T}}$ did not ferment glycerol in anaerobic freshwater medium, but the present study found that $P$. fermentans DSM $17108^{\mathrm{T}}$ could grow on glycerol in RJ medium and formed propionate as the dominant product.

Table 1. Characteristics that differentiate strain $\mathrm{SHI}-1^{\top}$ from related taxa

Strains: 1, Pelosinus defluvii sp. nov. SHI- $1^{\mathrm{T}}$; Pelosinus fermentans DSM $17108^{\mathrm{T}} ; 3$, Sporotalea propionica DSM $13327^{\mathrm{T}}$. All data were taken from this study. The results for strain SHI-2 were identical to those for strain SHI- $1^{\mathrm{T}}$. + , Positive; - , negative.

\begin{tabular}{|lccc|}
\hline Characteristic & $\mathbf{1}$ & $\mathbf{2}$ & $\mathbf{3}$ \\
\hline Cell dimensions $(\mu \mathrm{m})$ & & & \\
$\quad$ Width & $0.6-1$ & 0.6 & $0.5-0.7$ \\
Length & $2-7$ & $2-6$ & $2.2-12$ \\
DNA G+ C content $(\mathrm{mol} \%$, HPLC) & 39.2 & 39.4 & 38.6 \\
Temperature for growth $\left({ }^{\circ} \mathrm{C}\right)$ & $10-42$ & $10-42$ & $15-37$ \\
Optimum pH for growth & $7.0-7.5$ & $7.0-7.5$ & $6.5-7.0$ \\
Growth on: & & & \\
Amygdalin & - & + & - \\
Arabinose & - & + & + \\
Cellobiose & - & + & + \\
Erythritol & - & + & - \\
Mannitol & - & + & + \\
myo-Inositol & - & + & - \\
Rhamnose & - & - & + \\
Salicin & - & + & - \\
Sorbitol & - & + & - \\
Organic acids from fermentation of: ${ }^{*}$ & & & \\
Fumarate & $\mathrm{P}, \mathrm{A}, \mathrm{S}$ & $\mathrm{P}, \mathrm{A}$ & $\mathrm{S}, \mathrm{A}$ \\
Glycerol & $\mathrm{P}, \mathrm{A}$ & $\mathrm{P}$ & $\mathrm{P}$ \\
\hline
\end{tabular}

${ }^{*}$ Major products listed in stoichiometric order: A, acetate; P, propionate; s, succinate.
The organic acids produced from cultures grown in RJ medium supplemented with fumarate, glucose, glycerol and $\mathrm{H}_{2}+\mathrm{CO}_{2}$ were measured using an ion chromatograph (ICS-2000; Dionex) equipped with an IonPac AS11-HC column and ASRS-ULTRA II $(4 \mathrm{~mm})$ suppressor and conductivity detector. The sample injection volume was $100 \mu$ l. Elution was performed with $\mathrm{KOH}(1.5 \mathrm{mM}$ for 10 min then ramping to $30 \mathrm{mM}$ at a rate of $1.6 \mathrm{mM}$

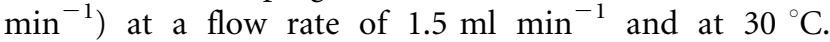
Retention times and peak areas of fermentation products were compared with those of standards, which included acetate, butyrate, formate, lactate, propionate, pyruvate and succinate. Hydrogen concentrations in the headspace gas were analysed by gas chromatography as described by Van Ginkel et al. (2001). From glucose fermentation, all four test strains produced propionate and acetate. From glycerol fermentation, strains SHI- ${ }^{\mathrm{T}}$ and $\mathrm{SHI}-2$ produced propionate and acetate while P. fermentans DSM $17108^{\mathrm{T}}$ and S. propionica DSM $13327^{\mathrm{T}}$ produced only propionate. From fumarate fermentation, strains $\mathrm{SHI}-1^{\mathrm{T}}$ and SHI-2 produced propionate, acetate and succinate while $P$. fermentans DSM $17108^{\mathrm{T}}$ produced only propionate and acetate and S. propionica DSM $13327^{\mathrm{T}}$ produced only succinate and acetate (Table 1). None of the strains tested produced acetate from $\mathrm{H}_{2}+\mathrm{CO}_{2} \cdot \mathrm{H}_{2}$ was not detected at $>1 \%(\mathrm{v} / \mathrm{v})$ in the headspace of serum bottles supplied with fumarate, glucose or glycerol as substrates, indicating that it is not a major product of fermentation.

The ability to reduce thiosulfate $(10 \mathrm{mM})$, sulfite $(10 \mathrm{mM})$, sulfate $(10 \mathrm{mM}), \mathrm{Fe}(\mathrm{III})$ citrate $(45 \mathrm{mM})$ and $\mathrm{Fe}(\mathrm{III})$ nitriloacetic acid $(10 \mathrm{mM})$ was assessed in Hungate tubes containing anaerobic PY broth supplemented with $10 \mathrm{mM}$ acetate. The headspace gas comprised $\mathrm{N}_{2} / \mathrm{CO}_{2}(80: 20$, v/v). Following inoculation (exponential growth-phase culture grown in PY broth amended with $10 \mathrm{mM}$ glucose, $2 \%$, v/v), tubes were incubated at $33{ }^{\circ} \mathrm{C}$ for 7 days with shaking at 120 r.p.m. The ability to reduce sulfite, sulfate and thiosulfate was assessed by measuring sulfide accumulation relative to uninoculated controls, as described by Kelly \& Wood (1998). The ability to reduce $\mathrm{Fe}(\mathrm{III})$ citrate and $\mathrm{Fe}(\mathrm{III})$ nitriloacetic acid was assessed by measuring $\mathrm{Fe}(\mathrm{II})$ accumulation relative to uninoculated controls, as described by Lovley \& Phillips (1986). Strains SHI- $1^{\mathrm{T}}$, SHI-2, P. fermentans DSM $17108^{\mathrm{T}}$ and S. propionica DSM $13327^{\mathrm{T}}$ did not reduce thiosulfate, sulfite or sulfate to sulfide, but they reduced $\mathrm{Fe}(\mathrm{III})$ citrate, with $\mathrm{Fe}(\mathrm{II})$ accumulating to concentrations of $4,3,4$ and $2 \mathrm{mM}$, respectively, and reduced $\mathrm{Fe}(\mathrm{III})$ nitriloacetic acid, with $\mathrm{Fe}(\mathrm{II})$ accumulating to concentrations of $1.3,2.5,2.1$ and $2.5 \mathrm{mM}$, respectively. Shelobolina et al. (2007) observed reduction of $\mathrm{Fe}(\mathrm{III})$ citrate, but not $\mathrm{Fe}(\mathrm{III})$ nitriloacetic acid, by $P$. fermentans $\mathrm{R} 7^{\mathrm{T}}$; however, their medium did not contain a fermentable substrate, whereas the PY broth used here contained yeast extract, which is a fermentable substrate for this strain.

The ability to grow aerobically was assessed in aerobic PYG broth lacking cysteine hydrochloride as a reducing agent and without $\mathrm{NaHCO}_{3}$. The inoculum was $1 \%(\mathrm{v} / \mathrm{v})$ and 
the cultures were incubated at $33{ }^{\circ} \mathrm{C}$ with shaking (150 r.p.m.) for 8 days. None of the strains grew under aerobic conditions. Good growth was observed in positive controls, which consisted of the same broth made anaerobically (headspace gas $\mathrm{N}_{2}$, reduced with cysteine hydrochloride) and inoculated and incubated at the same time.

The ability to use chlorinated solvents as electron acceptors was examined in $25 \mathrm{ml}$ serum bottles containing $10 \mathrm{ml}$ of titanium citrate and cysteine reduced anaerobic basal medium (Moe et al., 2009) amended with acetate, lactate, pyruvate and ribose (each $2 \mathrm{mM}$ ) and also in 1/10 PY broth. The following chlorinated solvents $(0.5 \mathrm{mM}$ concentration in the aqueous phase) were each tested separately: 1,1,2-trichloroethane, 1,2-dichloroethane, tetrachloroethene, trichloroethene, cis-1,2-dichloroethene and 1,2-dichloropropane. The headspace gas consisted of $\mathrm{N}_{2} /$ $\mathrm{CO}_{2} / \mathrm{H}_{2} \quad(80: 10: 10, \mathrm{v} / \mathrm{v})$. Incubation was at $30{ }^{\circ} \mathrm{C}$ for 6 weeks. Analysis of chlorinated solvents and potential dechlorination products was determined by GC as described by Yan et al. (2009). None of the strains transformed any of the chlorinated solvents under the conditions tested.

Because the cellular morphology and substrate utilization profiles for strains SHI- $1^{\mathrm{T}}$ and SHI-2 were identical and the 16S rRNA gene sequences shared high similarity, the cellular fatty acids, polar lipids, $\mathrm{G}+\mathrm{C}$ content and DNADNA relatedness were determined for only strain SHI- $1^{\mathrm{T}}$, P. fermentans DSM $17108^{\mathrm{T}}$ and S. propionica DSM $13327^{\mathrm{T}}$.

For cellular fatty acid analysis, cells grown in PYG broth for $24 \mathrm{~h}$ at $30{ }^{\circ} \mathrm{C}$ were harvested in mid-exponential growth phase by centrifugation at $3500 \mathrm{~g}$ for $15 \mathrm{~min}$. Fatty acids were extracted, saponified and methylated at the BCCM/ LMG (Ghent, Belgium) using the Microbial Identification System (Sherlock version 3.10; MIDI) and analysed by GC (Sasser, 1990) using a 6890N gas chromatograph (Agilent Technologies). Compounds were identified using the MIDI MOORE library version 5.0 (for VPI broth-grown anaerobes in PYG broth). Although differing somewhat in relative proportions, the major cellular fatty acids in strain SHI- $1^{\mathrm{T}}, P$. fermentans DSM $17108^{\mathrm{T}}$ and S. propionica DSM $13327^{\mathrm{T}}$ were identical (Table 2). With the exception of iso- $\mathrm{C}_{13.0}$, which was not detected in strain $\mathrm{SHI}-1^{\mathrm{T}}$ but comprised 0.3 and $1.0 \%$ of the total fatty acids in $P$. fermentans DSM $17108^{\mathrm{T}}$ and S. propionica DSM $13327^{\mathrm{T}}$, respectively, all of the other cellular fatty acids detected were common to all strains. The fatty acids comprised straight-chain saturates, terminally branched saturates, monoenoics, hydroxy fatty acids and dimethyl aldehydes.

For polar lipid analysis, cells grown in PYG broth for $48 \mathrm{~h}$ at $30{ }^{\circ} \mathrm{C}$ were harvested by centrifugation at $3500 \mathrm{~g}$ for 15 min at $4{ }^{\circ} \mathrm{C}$. The polar lipids were analysed as described by Ross \& Grant (1985). The polar lipids of all strains were practically identical and contained aminophospholipids, including phosphatidylethanolamine and phosphatidylserine, as well as at least one other unidentified aminophospholipid and an unknown phospholipid (Fig. S1, available in IJSEM Online).
Table 2. Comparison of cellular fatty acid compositions of strain $\mathrm{SHI}-1^{\top}$ and related taxa

Strains: 1, Pelosinus defluvii sp. nov. SHI- ${ }^{\mathrm{T}}$; Pelosinus fermentans DSM $17108^{\mathrm{T}} ; 3$, Sporotalea propionica DSM $13327^{\mathrm{T}}$. All data were taken from this study. Values are percentages of total gas chromatogram peak area. Fatty acids consisting of $<1 \%$ in all strains are not shown.

\begin{tabular}{|c|c|c|c|}
\hline Fatty acid (\%) & 1 & 2 & 3 \\
\hline $\mathrm{C}_{9: 0}$ & 1.7 & 1.4 & 0.3 \\
\hline $\mathrm{C}_{10: 0}$ & 1.8 & 2.8 & 0.9 \\
\hline iso- $\mathrm{C}_{11: 0}$ & 4.0 & 3.6 & 3.5 \\
\hline $\mathrm{C}_{11: 0}$ & 3.6 & 4.9 & 3.3 \\
\hline Unknown $^{\star}$ & 6.4 & 5.2 & 9.1 \\
\hline iso- $\mathrm{C}_{13: 0}$ & - & 0.3 & 1.0 \\
\hline $\mathrm{C}_{13: 0}$ & 0.5 & 1.0 & 1.4 \\
\hline Summed feature $2 \dagger$ & 3.9 & 5.1 & 5.9 \\
\hline $\mathrm{C}_{14: 0}$ & 0.7 & 1.9 & 1.4 \\
\hline iso- $\mathrm{C}_{13: 0} 3-\mathrm{OH}$ & 4.6 & 1.2 & 5.6 \\
\hline $\mathrm{C}_{14: 1} \omega 7 c \mathrm{DMA}$ & 1.3 & 0.9 & 0.5 \\
\hline $\mathrm{C}_{14: 0} \mathrm{DMA} \neq$ & 10.0 & 12.4 & 15.2 \\
\hline iso- $\mathrm{C}_{15: 0}$ & 0.4 & 0.5 & 1.3 \\
\hline Summed feature $4 \dagger$ & 25.8 & 24.8 & 15.0 \\
\hline $\mathrm{C}_{15: 1} \omega 6 c$ & 1.4 & 0.8 & 0.6 \\
\hline $\mathrm{C}_{15: 0}$ & 5.9 & 5.5 & 8.3 \\
\hline $\mathrm{C}_{16: 1} \omega 9 c$ & 2.4 & 4.7 & 3.1 \\
\hline $\mathrm{C}_{16: 1} \omega 7 c$ & 2.3 & 2.2 & 1.0 \\
\hline $\mathrm{C}_{16: 0}$ & 1.3 & 1.9 & 2.4 \\
\hline Summed feature $8 \dagger$ & 12.5 & 6.0 & 7.5 \\
\hline $\mathrm{C}_{17: 1} \omega 6 c$ & 1.2 & 0.7 & 0.8 \\
\hline $\mathrm{C}_{17: 0}$ & 1.3 & 0.5 & 2.1 \\
\hline $\mathrm{C}_{18: 2} \omega 6,9 c$ & 0.3 & 0.9 & 0.4 \\
\hline
\end{tabular}

${ }^{*}$ Constituents with an equivalent chain-length of 12.44 were identified as $\mathrm{C}_{11: 0} 3-\mathrm{OH}$ using the MIDI TSBA 50.0 (rev. 5.0) peak naming table.

$\dagger$ Summed features represent two or three fatty acids that cannot be separated by the Microbial Identification System. Summed feature 2 consisted of $\mathrm{C}_{12: 0} 3-\mathrm{OH}$ and/or $\mathrm{C}_{13: 0}$ DMA. Summed feature 4 consisted of $\mathrm{C}_{15: 1} \omega 8 \mathrm{c}$ and/or $\mathrm{C}_{15: 2}$. Summed feature 8 consisted of $\mathrm{C}_{17: 1} \omega 8 c$ and/or $\mathrm{C}_{17: 2}$.

\$Constituents with an equivalent chain-length of 14.47 were identified as a summed feature comprising one or more of $\mathrm{C}_{13: 0} 3$ $\mathrm{OH}$, iso- $\mathrm{C}_{15: 1} \mathrm{I}$ and iso- $\mathrm{C}_{15: 1} \mathrm{H}$ in the MIDI TSBA 50.0 (rev. 5.0) peak naming table.

For determination of DNA G $+\mathrm{C}$ content and DNA-DNA relatedness, genomic DNA was extracted from PYG-grown cells according to a modification of the procedure of Gevers et al. (2001). Genomic DNA G $+\mathrm{C}$ content was determined at the BCCM/LMG using the HPLC technique of Mesbah et al. (1989). Table 1 gives the means of three independent analyses of the same DNA sample. Shelobolina et al. (2007) reported the $\mathrm{G}+\mathrm{C}$ content of $P$. fermentans $\mathrm{R} 7^{\mathrm{T}}$ to be $41.0 \mathrm{~mol} \%$, which is slightly higher than the value of $39.4 \mathrm{~mol} \%$ determined in the present study. This difference may be due to the use of different methods for the determination of $\mathrm{G}+\mathrm{C}$ content. 
DNA-DNA hybridization was performed at the BCCM/ LMG at $38{ }^{\circ} \mathrm{C}$ in a solution containing $50 \%(\mathrm{v} / \mathrm{v})$ formamide using a modification (Goris et al., 1998; Cleenwerck et al., 2002) of the microplate method described by Ezaki et al. (1989). Four replicate hybridizations were performed and the averages were calculated. Reciprocal reactions were performed. The variation observed was within the limits of the method (Goris et al., 1998). DNA-DNA relatedness between strain SHI- $1^{\mathrm{T}}$ and $P$. fermentans DSM $17108^{\mathrm{T}}$ and $S$. propionica DSM $13327^{\mathrm{T}}$ was low (20 and $16 \%$, respectively; reciprocal 22 and $21 \%$, respectively). DNA-DNA relatedness between $P$. fermentans DSM $17108^{\mathrm{T}}$ and S. propionica DSM $13327^{\mathrm{T}}$ was also low (44\%; reciprocal $44 \%$ ). These results supported the classification of strain $\mathrm{SHI}-1^{\mathrm{T}}$ to a species distinct from the previously described members of the genera Pelosinus and Sporotalea. Likewise, the results supported the classification of $P$. fermentans DSM $17108^{\mathrm{T}}$ to a species separate from S. propionica DSM $13327^{\mathrm{T}}$.

Strains SHI- $1^{\mathrm{T}}$ and SHI-2 shared many similarities with $P$. fermentans and $S$. propionica. All were obligate anaerobes with cells that were straight or slightly curved rods and motile by means of peritrichous flagella. All formed endospores. They shared common cellular fatty acids (Table 2 ) and polar lipids and had similar G+C contents (Table 1). All produced propionate from the fermentation of glucose. Strains SHI- $1^{\mathrm{T}}$ and SHI-2 could be differentiated from $P$. fermentans on the basis that they did not grow on amygdalin, arabinose, cellobiose, erythritol, mannitol, myo-inositol, salicin or sorbitol (Table 1) and could be differentiated from S. propionica on the basis that they did not grow on arabinose, cellobiose, mannitol or rhamnose. Additionally, strains SHI- $1^{\mathrm{T}}$ and SHI-2 produced both propionate and acetate from fermentation of glycerol while $P$. fermentans and S. propionica produced only propionate. Products from fermentation of fumarate also served as a differentiating feature, with strains SHI- $1^{\mathrm{T}}$ and SHI-2 producing propionate, acetate and succinate, $P$. fermentans producing only propionate and acetate and $S$. propionica producing only succinate and acetate. The temperature range for growth of strains SHI- $1^{\mathrm{T}}$ and SHI-2 $\left(10-42{ }^{\circ} \mathrm{C}\right)$ was greater than that of $S$. propionica $\left(15-37^{\circ} \mathrm{C}\right)$.

The name S. propionica appeared on IJSEM Validation List no. 115 (Euzéby, 2007) 5 months after the valid publication of the name P. fermentans (Shelobolina et al., 2007). As such, the name Pelosinus has priority in the nomenclature. On the basis of the phylogenetic, chemotaxonomic and phenotypic properties determined in the present study, we propose that S. propionica (Boga et al., 2007) is renamed as Pelosinus propionicus comb. nov.

Hansel et al. (2008) reported that gene sequences most closely related to $P$. fermentans comprised a large percentage (49-100\%) of 16S rRNA clone libraries constructed from $\mathrm{Fe}(\mathrm{III})$-reducing, lactate-amended enrichment cultures from three geochemically contrasting soils in Tennessee $(\mathrm{pH}$ ranging from 4.5 to 7 ). The $16 \mathrm{~S}$ rRNA gene sequences that clustered most closely with members of the genera Pelosinus and Sporotalea and the related 'Psychrosinus fermentans' (Sattley et al., 2008) comprised $0.83 \%(918 / 110697)$ of sequences in a pyrosequencing library constructed from DNA extracted from groundwater at the Scenic Highway site from April to December 2009 in an area where molasses was injected into the subsurface to stimulate bioremediation of chlorinated solvents (unpublished data). This group of $16 \mathrm{~S}$ rRNA gene sequences comprised a much smaller percentage $[(0.019 \%,(7 / 37583)]$ of sequences in a library constructed from DNA extracted from groundwater collected from the nearby well SBP-017-B, from which the isolates were recovered and which was not impacted by subsurface injection of molasses. This suggests that addition of fermentable carbohydrates in bioremediation approaches may serve to increase the relative abundances of these microbial groups.

\section{Emended description of the genus Pelosinus}

The description is based on Shelobolina et al. (2007), Boga et al. (2007) and this study. Cells are Gram-stain-variable, motile, straight or slightly curved rods. Spore-forming. Sporangia are distinctly swollen. Obligately anaerobic. Mesophilic. Does not produce acetate from $\mathrm{H}_{2}+\mathrm{CO}_{2}$. Chemo-organotrophic with fermentative metabolism. Propionate is a major product of glucose fermentation. The major cellular fatty acids $(>10 \%$, MIDI MOORE version 5.0 database) are summed feature 4 (comprising $\mathrm{C}_{15: 1} \omega 8 c$ and/or $\left.\mathrm{C}_{15: 2}\right)$ and $\mathrm{C}_{14: 0}$ dimethyl aldehyde (DMA). Aminophospholipids, including phosphatidylethanolamine and phosphatidylserine, and other phospholipids are present. The DNA G $+\mathrm{C}$ content is $38-41 \mathrm{~mol} \%$. The type species is Pelosinus fermentans.

\section{Description of Pelosinus defluvii sp. nov.}

Pelosinus defluvii (de.flu'vi.i. L. gen. n. defluvii of waste, because the first isolation source was groundwater from a site contaminated with hazardous waste).

After incubation for 5 days at $33{ }^{\circ} \mathrm{C}$ on anaerobic PYG agar, colonies are circular, $1-3 \mathrm{~mm}$ in diameter, buff to offwhite, translucent, convex and smooth with entire margins. Cells are Gram-negative, straight or curved rods (0.6$1 \times 2-7 \mu \mathrm{m})$. Motile by peritrichous flagella. Grows at 10 $42{ }^{\circ} \mathrm{C}$ (optimum $30-37{ }^{\circ} \mathrm{C}$ ) and at $\mathrm{pH}$ 5.5-8.5 (optimum $\mathrm{pH}$ 7.0-7.5). Grows on Casamino acids, fructose, fumarate, glucose, glycerol, pyruvate and yeast extract, but not on adonitol, acetate, amygdalin, arabinose, 2,3-butanediol, butyrate, cellobiose, dulcitol, erythritol, ethanol, formate, fucose, glutamic acid, glycogen, $\mathrm{H}_{2}+\mathrm{CO}_{2}$, inulin, lactate, lactose, malonate, maltose, mannitol, melezitose, methanol, myo-inositol, propionate, pyrogallol, raffinose, rhamnose, salicin, salicylic acid, sorbitol, starch, succinate, sucrose, trehalose or xylan. The major products of glucose and glycerol fermentation are propionate and acetate. The major products of fumarate fermentation are propionate, acetate and succinate. The major cellular fatty acids ( $>5 \%$, MIDI MOORE version 5.0 database) are 
summed feature 4 (comprising $\mathrm{C}_{15: 1} \omega 8 c$ and/or $\mathrm{C}_{15: 2}$ ), summed feature 8 (comprising $\mathrm{C}_{17: 1} \omega 8 c$ and/or $\mathrm{C}_{17: 2}$ ) $\mathrm{C}_{14: 0}$ DMA and $\mathrm{C}_{15: 0}$. The DNA G $+\mathrm{C}$ content of the type strain is $39.2 \mathrm{~mol} \%$.

The type strain, SHI- $1^{\mathrm{T}} \quad\left(=\mathrm{NRRL} \quad \mathrm{Y}-59407^{\mathrm{T}}=\mathrm{LMG}\right.$ $\left.25549^{\mathrm{T}}\right)$, was isolated from chlorinated solvent-contaminated groundwater.

\section{Description of Pelosinus propionicus comb. nov.}

Pelosinus propionicus (pro.pi.o'ni.cus. N.L. neut. n. acidum propionicum propionic acid; N.L. masc. adj. propionicus pertaining to propionic acid, which the organism produces from various substrates).

Basonym: Sporotalea propionica Boga et al. 2007.

The emended description is based on Boga et al. (2007) and this study. Cells are long rods $(0.5-0.7 \times 2.2-12 \mu \mathrm{m})$. Cells appear singly or in pairs. Forms heat-resistant endospores. Motile by peritrichous flagella. Gram-staining-positive but Gram-negative with the $\mathrm{KOH}$ test. Catalase-negative. Ferments cellobiose, glucose, fructose, lactose, citrate, lactate, mannitol, oxaloacetate, glutamate and glycerol to propionate, acetate and $\mathrm{CO}_{2}$. L-Malate is fermented to acetate, succinate and propionate. Fumarate and aspartate are fermented to succinate and acetate. Does not utilize trehalose, methanol, ethanol, succinate, malonate, propionate, formate, acrylate, glyoxylate, acetate, vanillate, syringate or 3,4,5-trimethoxybenzoate. Cells possess B-type cytochromes. Does not form acetate from $\mathrm{H}_{2}$ and $\mathrm{CO}_{2}$. Nitrate and sulfate are not reduced. Resting cells reduce oxygen. Grows at $15-37{ }^{\circ} \mathrm{C}$ (optimum $30-37{ }^{\circ} \mathrm{C}$ ) and at pH 5.5-8.5 (optimum pH 6.5-7.0). The major cellular fatty acids ( $>5 \%$, MIDI MOORE version 5.0 database) are $\mathrm{C}_{14: 0} \mathrm{DMA}$, summed feature 4 (comprising $\mathrm{C}_{15: 1} \omega 8 c$ and/or $\mathrm{C}_{15: 2}$ ), $\mathrm{C}_{15: 0}$, summed feature 8 (comprising $\mathrm{C}_{17: 1} \omega 8 c$ and/or $\mathrm{C}_{17: 2}$ ), summed feature 2 (comprising $\mathrm{C}_{12: 0} 3-\mathrm{OH}$ and/or $\left.\mathrm{C}_{13: 0} \mathrm{DMA}\right)$ and iso- $\mathrm{C}_{13: 0}$ $3-\mathrm{OH}$.

The type strain, TmPN3 $^{\mathrm{T}}\left(=\mathrm{DSM} 13327^{\mathrm{T}}=\right.$ ATCC BAA$\left.626^{\mathrm{T}}\right)$, was isolated from the intestinal tract of the termite T. macrothorax. The DNA G $+\mathrm{C}$ content of the type strain is $38.6 \mathrm{~mol} \%$.

\section{Acknowledgements}

This research was funded by the Governor's Biotechnology Initiative of the Louisiana Board of Regents, the Enhancement of the LSU Hazardous Substance Research Center Environmental Biotechnology Initiative (grant number BOR\#015) and NPC Services. The authors thank Jean Euzéby for assistance with the etymology of the novel species.

\section{References}

Bae, H.-S., Rash, B. A., Rainey, F. A., Nobre, M. F., Tiago, I., da Costa, M. S. \& Moe, W. M. (2007). Description of Azospira restricta sp. nov., a nitrogen-fixing bacterium isolated from groundwater. Int $J$ Syst Evol Microbiol 57, 1521-1526.

Boga, H. I., Ji, R., Ludwig, W. \& Brune, A. (2007). Sporotalea propionica gen. nov. sp. nov., a hydrogen-oxidizing, oxygen-reducing, propionigenic firmicute from the intestinal tract of a soil-feeding termite. Arch Microbiol 187, 15-27.

Cleenwerck, I., Vandemeulebroecke, K., Janssens, D. \& Swings, J. (2002). Re-examination of the genus Acetobacter, with descriptions of Acetobacter cerevisiae sp. nov. and Acetobacter malorum sp. nov. Int $J$ Syst Evol Microbiol 52, 1551-1558.

Collins, M. D., Lawson, P. A., Willems, A., Cordoba, J. J., FernandezGarayzabal, J., Garcia, P., Cai, J., Hippe, H. \& Farrow, J. A. E. (1994). The phylogeny of the genus Clostridium: proposal of five new genera and eleven new species combinations. Int J Syst Bacteriol 44, 812-826.

Euzéby, J. (2007). List of new names and new combinations previously effectively, but not validly, published. Int J Syst Evol Microbiol 57, 893-897.

Ezaki, T., Hashimoto, Y. \& Yabuuchi, E. (1989). Fluorometric deoxyribonucleic acid-deoxyribonucleic acid hybridization in microdilution wells as an alternative to membrane filter hybridization in which radioisotopes are used to determine genetic relatedness among bacterial strains. Int J Syst Bacteriol 39, 224-229.

Gevers, D., Huys, G. \& Swings, J. (2001). Applicability of rep-PCR fingerprinting for identification of Lactobacillus species. FEMS Microbiol Lett 205, 31-36.

Goris, J., Suzuki, K.-I., De Vos, P., Nakase, T. \& Kersters, K. (1998). Evaluation of a microplate DNA-DNA hybridization method compared with the initial renaturation method. Can J Microbiol 44, 1148-1153.

Hansel, C. M., Fendorf, S., Jardine, P. M. \& Francis, C. A. (2008). Changes in bacterial and archaeal community structure and functional diversity along a geochemically variable soil profile. Appl Environ Microbiol 74, 1620-1633.

Holdeman, L. V., Cato, E. P. \& Moore, W. E. C. (1977). Anaerobe Laboratory Manual, 4th edn. Blacksburg, VA: Virginia Polytechnic Institute and State University.

Kane, M. D. \& Breznak, J. A. (1991). Acetonema longum gen. nov. sp. nov., an $\mathrm{H}_{2} / \mathrm{CO}_{2}$ acetogenic bacterium from the termite, Pterotermes occidentis. Arch Microbiol 156, 91-98.

Kelly, D. P. \& Wood, A. P. (1998). Microbes of the sulfur cycle. In Techniques in Microbial Ecology, pp. 31-57. Edited by R. S. Burlage, R. Atlas, D. Stahl, G. Geesey \& G. Sayler. New York: Oxford University Press.

Lovley, D. R. \& Phillips, E. J. P. (1986). Availability of ferric iron for microbial reduction in bottom sediments of the freshwater tidal Potomac river. Appl Environ Microbiol 52, 751-757.

Mesbah, M., Premachandran, U. \& Whitman, W. B. (1989). Precise measurement of the $\mathrm{G}+\mathrm{C}$ content of deoxyribonucleic acid by high performance liquid chromathography. Int J Syst Bacteriol 39, 159-167.

Moe, W. M., Yan, J., Nobre, M. F., da Costa, M. S. \& Rainey, F. A. (2009). Dehalogenimonas lykanthroporepellens gen. nov., sp. nov., a reductively dehalogenating bacterium isolated from chlorinated solvent-contaminated groundwater. Int J Syst Evol Microbiol 59, 2692-2697.

Powers, E. M. (1995). Efficacy of the Ryu nonstaining KOH technique for rapidly determining gram reactions of food-borne and waterborne bacteria and yeasts. Appl Environ Microbiol 61, 3756-3758.

Rainey, F. A., Ward-Rainey, N., Kroppenstedt, R. M. \& Stackebrandt, E. (1996a). The genus Nocardiopsis represents a phylogenetically coherent taxon and a distinct actinomycete lineage: proposal of Nocardiopsaceae fam. nov. Int J Syst Bacteriol 46, 1088-1092. 
Rainey, F. A., Ward-Rainey, N. L., Janssen, P. H., Hippe, H. \& Stackebrandt, E. (1996b). Clostridium paradoxum DSM $7308^{\mathrm{T}}$ contains multiple 16S rRNA genes with heterogeneous intervening sequences. Microbiology 142, 2087-2095.

Ray, A. E., Connon, S. A., Sheridan, P. P., Gilbreath, J., Shields, M., Newby, D. T., Fujita, Y. \& Magnuson, T. S. (2010). Intragenomic heterogeneity of the 16S rRNA gene in strain UFO1 caused by a 100bp insertion in helix 6. FEMS Microbiol Ecol 72, 343-353.

Rogosa, M. (1971). Transfer of Veillonella Prévot and Acidaminococcus Rogosa from Neisseriaceae to Veillonellaceae fam. nov., and the inclusion of Megasphaera Rogosa in Veillonellaceae. Int J Syst Bacteriol 21, 231-233.

Ross, H. N. M. \& Grant, W. D. (1985). Lipids in archaebacterial taxonomy. In Chemical Methods in Bacterial Systematics, pp. 290-291. Edited by M. Goodfellow \& D. E. Minnikin. New York: Academic Press.

Sasser, M. (1990). Identification of bacteria by gas chromatography of cellular fatty acids, MIDI Technical Note 101. Newark, DE: MIDI Inc.

Sattley, W. M., Jung, D. O. \& Madigan, M. T. (2008). Psychrosinus fermentans gen. nov., sp. nov., a lactate-fermenting bacterium from near-freezing oxycline waters of a meromictic Antarctic lake. FEMS Microbiol Lett 287, 121-127.

Sekiguchi, Y., Kamagata, Y., Nakamura, K., Ohashi, A. \& Harada, H. (2000). Syntrophothermus lipocalidus gen. nov., sp. nov., a novel thermophilic, syntrophic, fatty-acid-oxidizing anaerobe which utilizes isobutyrate. Int J Syst Evol Microbiol 50, 771-779.

Shelobolina, E. S., Nevin, K. P., Blakeney-Hayward, J. D., Johnsen, C. V., Plaia, T. W., Krader, P., Woodard, T., Holmes, D. E., Vanpraagh, C. G. \& Lovley, D. R. (2007). Geobacter pickeringii sp. nov., Geobacter argillaceus sp. nov. and Pelosinus fermentans gen. nov., sp. nov., isolated from subsurface kaolin lenses. Int J Syst Evol Microbiol 57, 126-135.

Stackebrandt, E., Sproer, C., Rainey, F. A., Burghardt, J., Päuker, O. \& Hippe, H. (1997). Phylogenetic analysis of the genus Desulfotomaculum: evidence for the misclassification of Desulfotomaculum guttoideum and description of Desulfotomaculum orientis as Desulfosporosinus orientis gen. nov., comb. nov. Int J Syst Bacteriol 47, 1134-1139.

Strömpl, C., Tindall, B. J., Jarvis, G. N., Lünsdorf, H., Moore, E. R. B. \& Hippe, H. (1999). A re-evaluation of the taxonomy of the genus Anaerovibrio, with the reclassification of Anaerovibrio glycerini as Anaerosinus glycerini gen. nov., comb. nov., and Anaerovibrio burkinabensis as Anaeroarcus burkinensis [corrig.] gen. nov., comb. nov. Int J Syst Bacteriol 49, 1861-1872.

Van Ginkel, S. V., Sung, S. \& Lay, J. J. (2001). Biohydrogen production as a function of $\mathrm{pH}$ and substrate concentration. Environ Sci Technol 35, 4726-4730.

Villemur, R., Constant, P., Gauthier, A., Shareck, M. \& Beaudet, R. (2007). Heterogeneity between $16 \mathrm{~S}$ ribosomal RNA gene copies borne by one Desulfitobacterium strain is caused by different 100-200 bp insertions in the $5^{\prime}$ region. Can J Microbiol 53, 116-128.

Widdel, F., Kohring, G. W. \& Mayer, F. (1983). Studies on dissimilatory sulfate-reducing bacteria that decompose fatty acids. III. Characterization of the filamentous gliding Desulfonema limicola gen. nov. sp. nov., and Desulfonema magnum sp. nov. Arch Microbiol 134, 286294.

Wolin, E. A., Wolin, M. J. \& Wolfe, R. S. (1963). Formation of methane by bacterial extracts. J Biol Chem 238, 2882-2886.

Wu, M., Ren, Q., Durkin, A. S., Daugherty, S. C., Brinkac, L. M., Dodson, R. J., Madupu, R., Sullivan, S. A., Kolonay, J. F. \& other authors (2005). Life in hot carbon monoxide: the complete genome sequence of Carboxydothermus hydrogenoformans Z-2901. PLoS Genet 1, e65.

Yan, J., Rash, B. A., Rainey, F. A. \& Moe, W. M. (2009). Isolation of novel bacteria within the Chloroflexi capable of reductive dechlorination of 1, 2, 3-trichloropropane. Environ Microbiol 11, 833-843. 